Winter 2014

\title{
Regular Soybeans: Translation and Framing in the Ontological Politics of a Coup
}

Kregg Hetherington

Concordia University, kregg.hetherington@concordia.ca

Follow this and additional works at: https://www.repository.law.indiana.edu/ijgls

Part of the Administrative Law Commons, and the International Law Commons

\section{Recommended Citation}

Hetherington, Kregg (2014) "Regular Soybeans: Translation and Framing in the Ontological Politics of a Coup," Indiana Journal of Global Legal Studies: Vol. 21 : Iss. 1 , Article 3.

Available at: https://www.repository.law.indiana.edu/ijgls/vol21/iss1/3

This Symposium is brought to you for free and open access by the Law School Journals at Digital Repository @ Maurer Law. It has been accepted for inclusion in Indiana Journal of Global Legal Studies by an authorized editor of Digital Repository @ Maurer Law. For more information, please contact rvaughan@indiana.edu.

\section{$\Psi$}

JEROME HALL LAW LIBRARY

INDIANA UNIVERSITY

Maurer School of Law
Blooming ton 


\title{
Regular Soybeans: Translation and Framing in the Ontological Politics of a Coup
}

\author{
KREGG HETHERINGTON ${ }^{*}$
}

\begin{abstract}
This paper argues for understanding the regulation and standardization of objects as fundamentally about "adding" to those objects rather than reducing or simplifying them. The analysis is based on the ethnographic study of regulatory politics in Paraguayan soybean production over the course of two decades in which the Paraguayan state increased its regulatory capacity immensely. By looking at very different forms of regulatory intervention, it shows that each regulatory moment can best be understood as a "translation" which adds to the complexity of the objects in question by adding new actors and concerns to their circulation. This provides a more dynamic way of understanding the politics of regulation than more common approaches that see regulation as technical and depoliticizing.
\end{abstract}

* Kregg Hetherington is professor of Anthropology at Concordia University in Montreal. He has a PhD in Sociocultural Anthropology from the University of California, Davis (2008). Since 2002, he has conducted ethnographic fieldwork in Paraguay. His work, exemplified by the book Guerrilla Auditors (Duke University Press 2011), explores the relationship between activist politics and law. The research on which this paper is based took place between 2010 and 2012, and involved extensive fieldwork and interviewing among state regulators and farmers during the administration of President Fernando Lugo (2008-2012). This paper would not have been possible without the generosity and openness of many farmers and functionaries in Paraguay, particularly those working in SENAVE. Marco Castillo, Alejandra Estigarribia, and Sofia Espíndola helped with the research in Asunción, which was funded by the Social Sciences and Humanities Research Council of Canada. The paper itself is the direct result of the provocations and conversations of the conference "Regulatory Translations: Expertise and Affect in Global Legal Fields" (May 16-18, 2013), organized by Boğaziçi University, Indiana Journal of Global Legal Studies, and Rice University. I am indebted to all those who participated, and particularly to Andrea Ballestero, Umut Türem, and Fred Aman for their generous invitation and later comments.

Indiana Journal of Global Legal Studies Vol. $21 \# 1$ (Winter 2014)

C Indiana University Maurer School of Law 


\section{INTRODUCTION $^{1}$}

In the last two decades, soybeans have become one of the world's most dominant food crops, carpeting vast swaths of arable land while insinuating themselves, often in disguise, into an astonishing variety of foods. ${ }^{2}$ Like any dominant global commodity, soybeans have also assembled new and powerful networks around themselves. ${ }^{3}$ This is nowhere more apparent than in Paraguay, a country for which soy production accounts for roughly fifty-five percent of the value of exports. ${ }^{4}$ Beginning in the late 1990 s, when agriculture and trade were very loosely regulated and Paraguay's economy was in crisis, soy began a ferocious expansion in the countryside, rebuilding the economy and the landscape around itself. Only in 2004 did the Paraguayan government seriously begin to intervene in the sector, attempting to regulate the expansion, to facilitate trade while checking its harms. For a government like Paraguay's, with a weak tax base, poor infrastructure, and a lack of technical expertise, asserting a regulatory presence was a major undertaking that came to generate front-page political intrigue and contributed to the recent fall of a government. The regulatory controversies surrounding soybeans, I'll argue here, are best understood by treating regulation as a form of ontological translation that multiplies, rather than contains, the objects of regulation.

1. In this article, if no specific citation is provided, the referenced facts were based on either anonymous interviews or the author's long involvement in the field.

2. See Sidney W. Mintz et al, introduction to THE WORLD OF SOY 1, 1-23 (Christine M. Du Bois et al. eds., 2008) (Sing.) (discussing how many of the most common processed food additives, like lecithin, are derived from soybean oil; and considering that since meat started to be produced in factories and feedlots, soybeans have become one of the primary ingredients of livestock feed).

3. The phrasing here is deliberate. Part of what makes entities like beans so fickle to regulate is that the networks of relations that are assembled around them are not obviously made by people. That is, when beans arrive, the world changes, whether people intend it to or not. Throughout this paper I use the term "network" to describe this kind of process, alluding to the "actor-network theory." For a broad introduction to the actornetwork theory, see JOHN LAW, AFTER METHOD: MESS IN SOCIAL SCIENCE RESEARCH (2004) and Bruno Latour, REASSEMbling THE SocIAL: AN INTROdUCtion to ACTORNETWORK-THEORY (2005). For a broad discussion of this way of understanding non-human entities, see JANE BENNETT, VIBRANT MATTER: A POLITICAL ECOLOGY OF THINGS (2010).

4. See OXfam International, The Soy Mirage: The limits of Corporate Social Responsibility: The Case of the Company Desarrollo agrícola del Paraguay, 16 (2013), available at http://www.google.com/url?sa=t\&rct=j\&q=\&esrc=s\&frm=1\&source=we $\mathrm{b} \& \mathrm{~cd}=1 \& \mathrm{cad}=\mathrm{rja} \& u a c t=8 \& \mathrm{ved}=0 \mathrm{CCQQFjAA} \& \mathrm{url}=\mathrm{http} \% 3 \mathrm{~A} \% 2 \mathrm{~F} \% 2 \mathrm{Fwww} .0 \times$ fam.org $\% 2 \mathrm{Fsi}$ tes\%2Fwww.oxfam.org\%2Ffiles\%2Frr-soy-mirage-corporate-social-responsibility-paraguay -290813-en.pdf\&ei=t_YaU_q0KsWbygGfvIDADA\&usg=AFQjCNFEE6v_bRzhgFSWQvLkF WS3dZjG6g. 
This paper will follow three moments of regulatory change that, over the course of a decade, translated Paraguay's excessive mega-crop. Soybeans are excessive not only in their expanse but in the complexity of the assemblage they drag into being. They are ontologically excessive, hard to get a handle on, and hard to bring into line with specific political positions and policy goals. In fact, because soybeans are already beings of complex ecological, political, and economic entanglements, and those working in the regulatory vein are always making new connections, soybeans subject to regulation are more rather than less complex. Regulations may temporarily manage to stabilize soybeans for the purpose of creating new connections, but, on the whole, they merely add to the vibrancy and multiplicity of the objects, potentially rendering them more volatile. ${ }^{5} \mathrm{I}$ argue that focusing on those regulatory interventions that cause objects to proliferate helps us to reposition one of the most common analytic tropes about regulation in both its normative and critical versions-the framework. Part of the problem with the idea of regulation as framing is that it emphasizes regulation's role in limiting objects and processes. And yet, limitation is only a small part of what regulations accomplish. If, by contrast, we see regulation as primarily additive, we can get a very different, and I would argue a more helpful, purchase on the politics of regulation.

In Paraguay, the multiplicity and volatility of regulatory objects was perhaps most obvious after a "parliamentary coup" in 2012 that was very much about who and what could participate in the regulation of soybeans. ${ }^{6}$ In national elections in 2008, the conservative Colorado Party was defeated for the first time in sixty-one years by an unlikely coalition of the pro-market Liberal Party and leftist activists, including environmentalists and peasant groups that had coalesced around the charismatic leadership of Fernando Lugo, a defrocked left-wing bishop. ${ }^{7}$ Lugo's experiment with social democracy was very tepid by most standards. Nonetheless, most conservatives and elites in Lugo's country reviled him, and, after four years of suffering his presence, they finally organized his ouster last June. ${ }^{3}$ Strangely, it seemed at the time, the

5. This discussion of the "excessiveness of things," is inspired by Jane Bennett's work on the irreducibility of vibrant matter. JANE BENNETT, VIBRANT MATTER: A POLITICAL ECOLOGY OF THINGS (2010).

6. The term "parliamentary coup" is used by critics to describe what was in fact a highly irregular impeachment process that its proponents argue was constitutional, but which drew widespread condemnation in the region.

7. Hugh O'Shaughnessy \& Edgar V. Ruiz Díaz, The Priest of Paraguay: Fernando Lugo and the Making of a Nation, 30 BULL. OF LATIN AM. RES. 100-101 (2010).

8. Most tellingly, the coup was made possible by fission in his coalition, between those who promoted building up the regulatory infrastructure to facilitate trade, and those who saw regulation as primarily about protecting citizens. 
attack on Lugo's government centered on a low-profile, foreign-educated environmentalist named Miguel Lovera, whom Lugo had named as head of the phytosanitary regulation agency, Servicio Nacional de Calidad y Sanidad Vegetal y de Semillas (SENAVE). ${ }^{9}$ Overnight, SENAVE went from being an invisible agency concerned primarily with measuring the purity of plant material and agrichemicals to being the target of a concerted two-year propaganda campaign that increased until Lugo was deposed. At the center of the campaign to vilify Lovera and oust Lugo was a formidable organization called the Union de Gremios Productivos (UGP), made up of spokespeople for the soybean industry.

When I first started asking Lovera's team why they thought the UGP's attacks were so vicious, most claimed that SENAVE presented two dangers: it could limit profitable agricultural practices of the industry, and it could reveal its illegal practices. ${ }^{10}$ This story makes some sense: as with everything else in Paraguay, the soy industry grew up relying on contraband chemicals and seeds, questionable and dangerous labor practices, violent land acquisitions, a lack of environmental controls, and the bribery of police and inspectors. But this only takes us so far. In fact, the industry itself had lobbied for the creation and professionalization of SENAVE to make the soy sector more transparent to international partners. The UGP had not only willingly limited some of these practices; it also paid for the service. Moreover, neither before nor after Lovera's appointment did SENAVE ever produce damning large-scale evidence of industry wrongdoing or of the overall harmfulness of soy cultivation, and no one ever questioned the data produced by the agency under Lovera. This was neither a fight about limitation nor about information. It was, I suggest, a fight over what Lovera's team had done to soybeans by becoming part of their network.

\section{Framing AND Translating}

My evocation of the irreducible ontology of soybeans is meant as both a statement about regulation itself and a methodological caution about how we critique governmental processes. The dominant trope in thinking about regulation is the "framework," a practice of limiting, containing, and disciplining. I suggest that we might open up the concept of the framework by extending Michel Callon's provocative work

\footnotetext{
9. National Plant and Seed Health and Quality Service.

10. This paper is based on three years of intermittent fieldwork in SENAVE and other agencies related to soy regulation in Paraguay, which is still ongoing.
} 
on the performance of markets. ${ }^{11}$ Callon argues that markets are constructed through acts of "enframing," and such acts include the work of economists who describe them. For Callon, economists do not stand outside their objects of study, but as translators enroll themselves into the network of the market themselves. Such regulatory interventions may be limiting (a frame's purpose is after all to exclude, i.e. to "cut the network"12 of possible associations), but they are also additive, since they produce a set of relationships that was not there before, including the relationship with economists. The same could be said of the inspectors, environmentalists, crop scientists, and epidemiologists who try to produce knowledge about soybeans. One reason this is important is that the sociology of regulation often falls into the descriptive rut of defining regulatory politics as the battle over the contexts of activities and objects imagined to be separate from what they contain. This is true both of normative approaches to regulation and critical ones that see regulation as disciplinary or exclusionary and thereby proceed by playing one frame (the one presumed to be enacted by the regulator) against another (some larger context, often called "the social" or "the environment").

At times, of course, these approaches are both useful and appropriate. But the closer one gets ethnographically to the people involved in regulation, the less it seems to make sense to understand regulation as mere boundary-making. This raises both an analytic and a political quandary. The problem was quite explicit when people like Lovera-who had spent his professional life critiquing the government from without-became part of Lugo's government between 2008 and 2010. Many of these people initially felt that the position would give them a chance to curtail the most savage aspects of capitalism and environmental predation; that is, regulation would be an extension, maybe even an operationalization (however incomplete) of their critical work. Predictably, many wondered whether they would be compromising their principles by becoming part of the process and breaching the distance from power that had once made it possible to vociferously critique the state. Not unlike the standard-setters Yasmine Chahed described in her contribution to this volume, activists-turnedfunctionaries in Lugo's government found themselves worrying about the line between radical critique and bureaucratic innovation. Having endured the suppression of their ideas and values by Alfredo Stroessner's dictatorship during the Cold War and disappointment in

11. See Michel CALlon, Introduction: The embeddedness of economic markets in economics, in THE LAWS OF THE MARKETS 1.57 (Michel Callon ed., 1998).

12. See Marilyn Strathern, Cutting the Network, 2 J. RoYal ANTHROPOLOGICAL INST. 517,522 (1996). 
the meager democratic transition that followed his ouster but left his Colorado Party in power, activists spent the next two decades as vociferous and active critics of anything the government did. ${ }^{13}$ The outcome of the 2008 election, and the appointment of many of these people to important civil service jobs, required activists to engage in a certain degree of intellectual reflection and rethinking. As one such new civil servant told me in 2010 , "[I]t was hard at first. We'd all be sitting around the table and people would start denouncing the government like we all do. And then someone would have to say, yeah, but wait a second, we are the government now. What are we going to do about it?"14

That simple question, familiar to so many progressives who, at some point, have either lost faith in, or actually experienced, a much-hopedfor revolution, is very similar to the analytic moment that gave rise to the sociology of translation in the 1980s. For Callon, the repudiation of critique as mere negation and destruction requires a new way of accounting for, and engaging with, power. ${ }^{15}$ In an early iteration of this argument, Callon and Bruno Latour insist succinctly, "In order to grow we must enrol [sic] other wills by translating what they want and by reifying this translation in such a way that none of them can desire anything else any longer."16 So while Paraguayan bureaucrats and activists do not use the concept of "translation" to describe what they do, I suggest that the way they operated and thought under Lugo's mandate was quite similar to Callon's approach. ${ }^{17}$ It began with the realization

13. See Kregg Hetherington, Guerrilla Auditors: The Politics of Transparency IN NEOLIBERAL PARAgUAY 25-65 (2011) (elaborating my analysis of this group of intellectuals, showing how much the disappointment with democratic reforms shaped their analysis of government and society between 1989 and 2008).

14. This quote comes from an anonymous interview with one of the top civil servants in SENAVE. The interview was conducted in person outside of the office (though during work hours) in July 2010.

15. Michel Callon, Why Virtualism Paves the Way to Political Impotence: A Reply to Daniel Miller's Critique of The Laws of the Markets, ECON. Soc. EUR. ELEC. NEWSL., Feb. 2005, at $3-20$.

16. Michel Callon \& Bruno Latour, Unscrewing the Big Leviathan: How Actors MacroStructure Reality and How Sociologists Help Them to Do So, in ADVANCES IN SocIAL Theory and METHODOLOGY 296 (Aaron Victor Cicourel \& K. Knorr-Cetina eds., 1981).

17. The implication here is that there is a historical reason why the sociology of translation becomes prominent toward the end of the Cold War, and why it is still useful for describing regulatory practices in the present. Given more space it would be nice to explore how the concept of translation itself has shifted in social theory from its early association with critical theory to its more common uses now in actor-network theory. The early accusation that ANT is apolitical parallels quite closely the worry among activists that they could not work for the state without being coopted. Ballestero's paper in this collection complexifies the question somewhat, by showing how a critical notion of translation (Walter Benjamin's) can also be used to arrive at a very similar sense of 
that the powerful relationship between state regulators and agrarian capitalists did not primarily operate by suppressing oppositional voices, as it arguably had during the Stroessner years. Instead, regulators and capitalists worked together by translating other interests into the creation of new, stronger assemblages. It followed that they needed to do the same to use government to create positive change.

The following analysis adds another layer to this parallelism by retelling some of the history of soybeans as a series of translations, following the objects on which regulation is supposed to operate. Each of these moments begins with soy as a complex and multiple assemblage and then shows how those assemblages are converted with the help of particular kinds of regulatory actors. ${ }^{18}$ Unsurprisingly, in each of these moments of translation, we find particular sorts of human characters acting as mediators who, not unlike the Sultan of Johor in Iza Hussin's account, produce novel associations out of their own interstitial positions: ${ }^{19}$ Brazilian migrants in Paraguay, foreign-educated technicians, and activist bureaucrats. Some of these translations are quite explicit, as in the attempts by national and international organizations to create new information-sharing networks. Others are much less so, like the implicit arbitraging of regulatory differences between Brazil and Paraguay carried out by migrants.

Insofar as each translation offers a moment for defining soybeans as singular, it also opens up new ways of appreciating them as plural, and, therefore, opening up new forms of association and new political possibilities. Indeed, built into the very concept of translation is the idea that two things can be the same while different. ${ }^{20}$ Each regulatory translation, far from reducing the complexity of the soybeans, only

regulation's additive qualities. See generally Andrea Ballestero, What Is in a Percentage? Calculation as the Poetic Translation of Human Rights, 21 IND. J. GLOBAL LEGAL STUD. 27 (2014). I don't resolve these tensions here but point them out as an interesting ethnographic field in which regulators work and anthropologists study them.

18. On "assemblage converters," see GILles DELEUZE \& FÉliX GuATTARI, A THOUSAND Plateaus: Capitalism AND Schizophrenia 324-25 (Brian Massumi trans., Athlone Press 1988) (1980); BENNETT, supra note 3 , at 42.

19. See MiCHEL CALlon, Some elements of a sociology of translation: domestication of the scallops and the fishermen of St. Brieuc Bay, in PowER, ACTION AND BELIEF: A NEW SOCIOLOGY OF KNOWLEDGE? 196, 204 (John Law ed., 1986) (explaining how the interdefinition of actors brings the addition of human actors, the fisherman and scientists, into the story); see also BRUNO LATOUR, REASSEMBLING THE SOCIAL: AN INTRODUCTION To ACTOR-NETWORK-THEORY, 108 (Oxford University Press 2005) (explaining how translations between mediators may generate associations). See generally Iza Hussin, Misreading and Mobility in Constitutional Texts: A Nineteenth Century Case, 21 IND. J. GLOBAL LEGAL STUD. 145 (2014).

20. See Timothy K. ChOY, ECologies of Comparison: AN ETHNOGRAPHY of ENDANGERMENT IN HONG KONG 94 (2011). 
produces new kinds of assemblages; indeed, it creates new kinds of soybeans. Soybeans are plants, food, and industrial raw materials. They are the vehicles of intellectual property rights and the means of arbitraging regulatory environments. They are the carriers of pests and dependents of pesticides. And they are both green gold and heinous land-occupiers. Each of these soybeans is an assemblage of regulatory relationships, which overlap but are not quite the same. It is in this gap of not-quiteness that regulatory politics is at its fiercest.

Regulatory politics is, therefore, very much an ontological politics. ${ }^{21}$ A well-known example of this comes from Annemarie Mol's description of medical practices in a Dutch hospital. ${ }^{22}$ Mol shows that the medical phenomenon we know as "atherosclerosis" is never more than a tenuously coordinated overlap between different objects produced by quite different premises and instruments. ${ }^{23}$ By eschewing the ontological reduction that would bring atherosclerosis into anything but momentary focus, Mol offers a subtle example for the study of more high-stakes variants of ontological politics, such as the regulation of a legume that is both an economic bonanza and a harbinger of death. ${ }^{24}$ Regulation never resolves this multiplicity. Instead, with each new attempt to contain soybeans, it produces a new soybean, partially connected to old soybeans. ${ }^{25}$

\section{First Translation: Intellectual Property on the Frontier}

Soybeans are a technically demanding crop with a key role in the reorganization of modern agriculture the world over throughout the twentieth century. ${ }^{26}$ They are grown for industrial processing to produce

21. See Annemarie Mol, Ontological Politics. A Word and Some Questions, in ACTOR NETWORK THEORY AND AFTER 74, 74-75 (John Law \& John Hassard eds., 1999).

22. ANNEMARIE MOL, THE Body Multiple: ONTOLOGY IN MEDiCAL PRACTICE (2002).

23. $I d$.

24. See Kregg Hetherington, Beans Before the Law: Knowledge Practices, Responsibility, and the Paraguayan Soy Boom, 28 CULTURAL ANTHRoPology 65, 67 (2013).

25. For the concept of the partial connection, I draw on Strathern's discussion of objects that are "neither singular nor plural, neither one nor many, a circuit of connections rather than joint parts." See MARILYN STRATHERN, PARTIAL CONNECTIONS 54 (1991); see also Marisol De La Cadena, Indigenous Cosmopolitics in the Andes: Conceptual Reflections Beyond "Politics," 25 CUlTURAL ANTHRopology 334, 347 (2010) (applying "partial connection" to an examination of Latin American indigeneity as a complex and political formation that is "more than one, but less than two").

26. For overviews of the importance of soybeans to changes in global agricultural regulation during the 20th century, see generally TowARDS A NEW POLITICAL ECONOMY OF AGRICULTURE 1 (William Friedland, et al. eds., 1991); Du BoIS, supra note 2, at 1; Jack Ralph Kloppenburg, First the Seed: The Political Economy of Plant Biotechnology, 1492-2000 1 (University of Wisconsin Press, 2d ed. 2004)(1988); RAJ 
oils, feeds, additives of all sorts, and most recently fuel. As a result, the commodity chain that soybeans articulate between breeders, producers, marketers, processors, and consumers is exceptionally long: behind every soybean is an array of political, corporate, chemical, and environmental interests. In Brazil and Argentina, Paraguay's two largest neighbors, soybean infrastructural development began in the 1930 s, and, by the 1970 s, the beans were planted on a large scale as part of sophisticated, state-run modernization schemes. ${ }^{27}$ Paraguayan agriculture was completely different, centered on the smallholder production of cotton, a crop that could be easily farmed with few tools and with little infrastructure. ${ }^{28}$ Soybeans entered the country quietly in 1976 , carried in and planted at a relatively small scale alongside other crops by impoverished migrants from Brazil who had been displaced by land concentration in their own country. ${ }^{29}$

By the 1990s, cotton and soybeans were equally important as export crops, together accounting for most of domestic production. ${ }^{30}$ The two crops belonged to two different territories and populations and had completely different relationships with the national government. Cotton, planted in departments nearest to Asunción by smallholder "campesinos,"31 was entirely connected to the Paraguayan Ministry of Agriculture. ${ }^{32}$ Soybeans, by contrast, had little to do with government at all and were still primarily planted by Brazilian migrants living in the

PATEL, STUFFEd AND STARVED: MARKETS, POWER AND THE HIDDEN BATTLE FOR THE WORLD FOOD SYSTEM (2007) 173-220.

27. See Ivan Sergio Freire de Sousa \& Rita de Cássia Milagres Teixeira Vieira, Soybeans and Soyfoods in Brazil, With Notes on Argentina, in THE WorLD of SoY, supra note 2 , at $234,236,245,251$.

28. For a while, tobacco was almost as important as cotton for the rural economy. For the sake of simplicity, I will not discuss Paraguay's gigantic ranching sector, which is intimately tied into this whole story. Before the introduction of soybeans, large-scale land use was primarily dedicated to ranching and logging, and a good deal of the current expansion of soybeans takes place on converted ranches.

29. For larger sociological descriptions of the Brazilian migration to Paraguay, see Sylvain Souchaud, Pionniers BrÉsiliens au PaRaguay [BRazilian Pioneers IN Paraguay] (2002) (Fr.), and Carlos Wagner, Brasiguaios: Homens Sem Pátria [BRAZIGUAYANS: MEN WITHOUT A COUNTRY] (1990) (Braz.).

30. See Richard Weisskoff, The Paraguayan Agro-Export Model of Development, 20 WORLD DEV. 1531, 1532-33 (1992).

31. I prefer to use the Spanish word "campesino" rather than the common English translation "peasant," because it is a term that people use to describe their political and ethnic identity in Paraguay as much as their economic activity.

32. See generally Basilio Nikiphoroff, EL Subdesarrollo RuRal Paraguayo-La Problemática algodonera [RuRal Paraguayan Underdevelopment-The Cotton ProBLEM] 31-43 (Intercontinental ed., 1994) (Para.) (detailing the state of landholding by small cotton farmers in Paraguay). 
eastern frontier areas closer to Brazil. ${ }^{33}$ They brought agricultural inputs from Brazil and sold their products there, using the long, poorly controlled border as points of transfer. They relied on Brazilian expertise, Brazilian laboratories, Brazilian regulatory guidelines, and Brazilian crushing facilities and shippers but were constrained by none of them. This absence of constraint was one of the primary reasons many of them had come to Paraguay in the first place, along with nonexistent taxes and cheap, available land. Most of the transnational corporations that serviced the sector avoided Asunción entirely and set up head offices in Ciudad del Este, the border city that is reputed to be one of the largest thoroughfares of contraband in the world. Poorer rural Paraguayans were enrolled in the sector primarily as laborers. As far as the soy sector was concerned, the Paraguayan state was backward and populist in a way that occasionally stirred up xenophobia, agitating the rural labor force. But it was also easily ignored. Under this arrangement, the soy sector grew to be an important part of the national economy but also remained separate from it and relatively independent from state interference.

Paraguayan soybeans were always a border phenomenon, made possible by the stark regulatory differences between Brazil and Paraguay. This first kind of translation is therefore a form of arbitrage, a speculative gamble that derives profit from moving an object between different regimes of value. ${ }^{34}$ Brazil had the industrial infrastructure while Paraguay had the cheap land. Brazil had access to markets made possible by long-standing regulatory developments, and Paraguay had low taxation. Brazil had expertise while Paraguay had soft law. The key actors here were also border subjects: Brazilians residing in Paraguay (known early by the pejorative label "Brasiguaios") who were uniquely positioned to take advantage of the resources on both sides.

In the 1990 s, these two competing crops underwent transformations that rearticulated the networks that supported them. For a variety of political, economic, and ecological reasons, the cotton harvest declined precipitously, plunging smallholders into deepening poverty while disarticulating them from their allies in a government mired in

33. See Andrew Nickson, Brazilian Colonization of the Eastern Border Region of Paraguay, 13 J. LATIN AM. STUD. 111, 111, 126 (1981); SOUCHAUD, supra note 29.

34. I take arbitrage in a general sense as a form of translation, which allows one to profit from the gap between the apparent sameness of a commodity across contexts and its contextual difference. See HIROKAZU MIYAZAKI, ARBITRAGING JAPAN: DREAMS OF CAPITALISM AT THE END OF FINANCE 30 (2013). For other examples of this usage, see ADRIANA PETRYNA, When Experiments Travel: Clinical Trials and the Global Search for human SUBJECTS 83 (2009). 
democratic transition, financial crisis, and austerity politics. ${ }^{35}$ Soybeans went through the opposite process, as the infrastructure for soybean production (all of it privately owned, and most of it run in Portuguese) increased throughout the 1990s, along with global prices for raw soybeans. Paraguay remained relatively isolated from common soybean pests, and cheap land and fertile soil continued to give farmers there a comparative advantage over neighboring countries. But it was really the arrival in 1999 of genetically-modified (GM) soybeans that dramatically complexified the network and enhanced the comparative advantage that Brazilian migrants could exploit in Paraguay. ${ }^{36}$

Roundup Ready soy was created by Monsanto for the U.S. soy belt in 1996 and was wildly successful because of its benefits for weed control. ${ }^{37}$ Able to resist applications of Roundup, a broad-spectrum herbicide, farmers could now clean their fields of weeds while the plants were growing with a simple pass of a crop duster. But the primary reason Monsanto, a chemical company, even branched into seed development at all has to do with U.S. patent law. Monsanto was looking to fill an earnings gap that was about to be created when its patent expired on Roundup (its brand name for glyphosate herbicide), its most profitable single product. ${ }^{38}$ The company could now control the distribution of soybean seeds in the United States, but more importantly, it could bind farmers into contracts that would keep them buying Roundup from Monsanto rather than generic glyphosate from anyone else ${ }^{39}$ Legislation that allowed them to patent gene-modification processes in the United States now made it possible to leverage profits from Roundup through a patent on soybeans rather than on the chemical itself. 40

Without legal protections in Paraguay, Monsanto had no way of reaping profits from the use of its technology there and did not have so

35. Kregg Hetherington, Guerrilla Auditors: The Politics of Transparency in NEOLIBERAL PARAGUAY 29-32 (2011).

36. See Hetherington, supra note 24 , at 71,73 , for a more detailed discussion of the relative changes in these crops.

37. Christine M. Du Bois \& Ivan Sergio Freire de Sousa, Genetically Engineered Soy, in THE WORLD OF SOY, supra note 2 , at 75.

38. Marie-Monique Robin, The World according to Monsanto: Pollution, CORRUPTION, AND THE CONTROL OF OUR FOOD SUPPLY 69-70 (2010).

39. See id. at 205.

40. The landmark case in the U.S. was Diamond us. Chakrabarty, 443 U.S. 303 (1980), which, in allowing a genetic engineer working for General Electric to patent an engineered bacterium, "facilitated the rapid emergence and development of the biotechnology or "life sciences' industry." ABby J. Kinchy, Seeds, Science, and Struggle: The Global POLITICS OF TRANSGENIC CROPS 104 (2012). 
much as a representative in the country until the early $2000 \mathrm{~s} .{ }^{41}$ Indeed, until 2005, it was actually illegal to plant genetically modified organisms of any kind in Paraguay. ${ }^{42}$ But the soybeans ended up there anyway, carried first to Argentina and then finally smuggled into Paraguay in unmarked white bags by Argentine seed vendors to be used alongside generic glyphosate. As Laura Foster highlights in her contribution to this volume, intellectual property (IP) regulation works by purifying and controlling, reducing the complex social histories of an organism to the presence or absence of a single gene. ${ }^{43}$ But moments of reductive translation also create the conditions by which organisms are able to create vast new networks around themselves. This of course is the point for a company that wishes to produce value, and this proliferation happens in ways that are neither completely planned nor controllable.

Once translated into this new situation, the soybeans articulated with different sorts of actors and networks, empowering new processes and soon exploding out into the Paraguayan frontier at a rate of 200,000 hectares per year. ${ }^{44}$ At least one of the conditions causing this was differential regulation. Paraguay's ban on planting GM seeds was copied from a similar ban in Brazil, with the primary difference being that, having long been embedded in the soybean production chain, the Brazilian state actually had the phytosanitary infrastructure to enforce its ban. ${ }^{45}$ Given the absence of this infrastructure, Brazilians planting soy in Paraguay had another difference to arbitrage. ${ }^{46}$ The increased use of pesticides associated with the beans also attracted regulatory pressure in Brazil and Argentina but not, in the first years, in Paraguay. So it was precisely the lack of a body like SENAVE, indeed

41. It still seems likely that the company was fully aware of the contraband introduction of its seeds into the country, and many Paraguayans, including critics and promoters of the industry, argue that it promoted the smuggling in the hopes that it would later be able to change Paraguayan law in its favor, which is exactly what happened.

42. Stella Semino et al., Grupo de Reflexión Rural, Paraguay Sojero: Soy EXPANSION AND ITS VIOLENT ATTACK ON LOCAL AND INDigENOUS COMMUNITIES IN PARAGUAY 16 (Nina Holland ed., 2006), available at http://www.non-gm-farmers.com/doc uments/Paraguayreport.pdf.

43. See generally Laura A. Foster, Critical Cultural Translation: A Socio-Legal Framework for Regulatory Orders, 21 IND. J. GLOBAL LEGAL STUD. 79 (2014).

44. See CAPECO, http://www.tera.com.py/capeco (last visited Mar. 8, 2014) (Para.).

45. Ivan Sergio Freire de Sousa \& Lawrence Busch, Standards and State-Building: The Construction of Soybean Standards in Brazil, in AgRICULTURAL STANDARDS: THE SHAPE OF THE GLOBAL FOOD AND FIBER SySTEM 125-35 (Jim Bingen \& Lawrence Busch eds., 2006) (Neth.).

46. Although Argentina did not have a similar ban, high export taxes (thirty-five percent on unprocessed soybeans compared with zero percent in Paraguay) made the difference there. 
the lack of an effective state of any sort, combined with the presence of a population of Brazilians and Brazilian descendants living on the border, that made soybeans in this period so extraordinarily profitable.

At the field level, the soybeans helped articulate both economic and political relationships. What Roundup Ready soybeans really did for Paraguayan farmers of a certain scale was allow them to simplify their weed-control programs, reducing the complexity of chemical inputs and machinery by allowing them to spray glyphosate whenever a problem presented itself. By extension, it also reduced the most fickle inputs, seasonal and day labor, usually hired from nearby campesino and indigenous communities to help control weeds. Soy farmers won twice: they got much higher returns on the crop, and they enhanced their separation from the Paraguayan state by cutting off their dependence on its clients. The boom of soybeans was, in equal measure, a horror for campesinos, who saw rural jobs drop off precipitously at the same time as deforestation and clouds of noxious chemicals became a standard part of the landscape, precipitating a further exodus of smallholders. ${ }^{47}$ Soy quickly became the focal point for a latent sense of the injustice of being rural and poor. ${ }^{48}$ For this reason, it is not surprising that, during the first decade of the twenty-first century, organized campesino groups all but declared war on soybeans, claiming that soy killed and trying to expunge it from the territory. ${ }^{49}$ Though they might not have been a matter of concern for Paraguay's regulators, soybeans had already bifurcated in the popular imagination and become the thing of an increasingly intense ontological politics in which soybeans were both singular and doubled. They were, depending on whom one asked, either "green gold" or "killer beans." 50 Both of these ways of speaking were allegories about soybeans, but, more to the point, both were ways of describing one's relationship to them, relationships that remained distinct. 51

47. See José Nicolás Morínigo Alcaraz, Auge de la producción RuRAL Y CRISIS Campesina [THE RISE of RuRal PRoduction ANd the PEasant Crisis] 59 (2009) (Para.); Kregg Hetherington, Privatizing the Private in Rural Paraguay: Precarious Lots and the Materiality of Rights, 36 AM. ETHNOLOGIST 224, 224 (2009). See generally ENCLAVE SOJERo: MERMA DE SOBERANÍA Y POBREZa [SOYBEAN ENCLAVE: POVERTY AND THE DECREASE OF Sovereignty] (Ramón B. Fogel \& Marcial Riquelme, eds., 2005) (Para.).

48. I mean this in the phenomenological sense described by Shklar as that "subjective sense of injustice and the sentiments that make us cry out for revenge." JUDITH N. SHKLAR, THE FACES OF INJUSTICE 49 (1990).

49. See Hetherington, supra note 24 , at 65.

50. Hetherington, supra note 24 , at 80 .

51. See generally JOHN LAW, AFTER METHOD: MESS IN SOCLAL SCIENCE RESEARCH (2004) (arguing that all knowledge is allegorical, creating understanding by weaving a relationship between unlike elements). 


\section{SECOND TRANSLATION: COMMODITIES AND INFORMATION}

The situation I have just described was viable for only a relatively short period, and the rapid proliferation of connections it generated also created pressure both within and without for new actors to become part of the assemblage. The next phase of soybean expansion in Paraguay resembles what Michel Callon calls "problematization," a form of translation in which different actors attempted to define the relationships around soybeans "in such a way as to establish themselves as an obligatory passage point in the network of relationships they were building." 52 That obligatory passage point would be SENAVE. It was originally proposed and designed by the Inter-American Development Bank in 1994, but it was not until a decade later that the necessary constellation of alliances came together to make it a reality. ${ }^{53}$

While Paraguayan soy remained relatively isolated from government view, international pressure was mounting for countries to update their phytosanitary regimes and harmonize standards, primarily with the rest of the region and with the European Union. The Rotterdam Convention of 1998 created a framework for increased communication about dangerous chemicals among signatories, developing regional controls for such pesticides as endosulfan, widely used in Paraguay in the 1990s. ${ }^{54}$ The United Nations Food and Agricultural Organization (FAO) and the Inter-American Institute for Cooperation in Agriculture (IICA) both made repeated presentations to the Paraguayan government about the need to bring Paraguay in line with the Codex Alimentarius and World Trade Organization guidelines about information sharing. In 2003, responding to these pressures, the Mercosur trading block (composed of Argentina, Brazil, Uruguay, and Paraguay) established a regional organization for harmonizing phytosanitary regulations across borders. ${ }^{55}$ For each of these groups,

52. Michel Callon, Some Elements of a Sociology of Translation: Domestication of the Scallops and the Fishermen of St Brieuc Bay, in POWER, ACTION AND BELIEF: A NEW SocIOLOGY OF KNOWLEDGE? 196, 204 (John Law ed., 1986).

53. See Banco Interamericano de Desarrollo, I Fase Programa de Diversificación y Modernización del Sector Agropecuario [Phase I Program of Diversification and Modernization of the Agricultural Sector], ATN/JF-4528-PR (May 18, 1994) (on file with the InterAmerican Development Bank).

54. Hebe Gonzales de Bobeda, La situación de los plaguicidas en el Paraguay [The Pesticide Situation in Paraguay], in Simposio INTERnacional Sobre Insecticidas, Plaguicidas y Desechos Tóxicos en el Paraguay [INTERnational Symposium on Insecticides, Pesticide, AND Toxic Waste IN Paraguay] 178, 182 (Organización Panamericana de la Salud ed., 1994) (Para.).

55. See Comite Regional de Sanidad Vegetal del Cono Sur [Regional CommitTeE on of PLANT PROTECTION fOR THE SOUTHERN CONE ], Estandar REgional EN 
Paraguay's lack of a functioning phytosanitary agency was compounded by an almost complete lack of technical infrastructure for producing standardized information.

For these actors, the period of 1999-2004 was one of frustration and failure to link their interests to the soybeans. These five years, associated with the government of Luis González Macchi, were years of deep poilitical and economic crisis for Paraguay. ${ }^{56}$ None of the international pressure created regulatory changes until a new executive, headed by Nicanor Duarte Frutos, took office in August 2004. Although of the same traditional Colorado Party as his predecessor, Duarte Frutos presented himself convincingly as a technocrat, and, in the first months of his mandate, built an entourage of people known for their ethical economic behavior. ${ }^{57} \mathrm{~A}$ key figure here was Ronaldo Dietze, a representative of Paraguay's most powerful farming cooperatives and trained in agrarian administration in Germany. It was Dietze who translated between international conventions and local farmers' interests, and drafted the legislation necessary to finally bring SENAVE into being. 58

What made Dietze's gambit successful was that the international bodies mentioned above were not the only ones pressuring for change. If the soy sector had benefited from a comparative lack of regulation in the first few years, it did not take long for the industry to start preparing to regulate themselves, primarily in the hopes of expanding its market beyond Brazil. The first step of market expansion required that Paraguayan producers be able to participate in the certification rituals that might make Paraguayan soy acceptable to foreign buyers, particularly from the European Union. This push would be led by largescale players in the industry, who no longer benefited directly from the lawlessness of the soybean trade and who wanted to be taken seriously at the international level. For them, the need for larger markets now

Protección Fitosanitaria [Regional. Standard for Plant Protection] § 3.15, at 1,4 (2003) (Arg.).

56. González Macchi went from being president of the Senate to president of the republic overnight after sitting president Cubas Grau was exiled at the very beginning of his mandate for his presumed role in the assassination of his own vice president. González Macchi had no credibility and little ability to govern, which is one of the reasons that the state did very little to respond to soybean expansion during his mandate. See HETHERINGTON, supra note 13 , at 57-60.

57. Id. at 59-60.

58. Like many people who rose to prominence under Duarte Frutos, Dietze was not part of the primary political structures of the two main political parties. Instead, he had become senator as part of a new party representing business interests and transparency. As an engineer and successful farmer, he had made his name as a neutral technocrat, and while he was an outsider to Paraguayan nationalist politics, he was a descendant-and this was key-not of Brazilians, but of Germans. 
outstripped the benefits of regulatory arbitrage. And for this they needed a new bean that could be more effectively commodified. ${ }^{59}$

As an illustration of these interests, it suffices to tell the odd story about how GM soybeans came to be legalized. In 2004, Monsanto, annoyed at what it saw as patent infringement but incapable of openly dealing with the Paraguayan government, managed, nonetheless, to get soy farmers to agree to pay a substantial royalty (four percent) directly to the company for the use of the illegal technology. ${ }^{60}$ The royalty deal between Monsanto and the UGP, facilitated by Dietze, showed the degree to which soybean producers were willing to be brought into costly hierarchical relationships of control if doing so might increase their credibility with multinational corporations and, finally, with overseas buyers. Most amazingly, the deal involved the Ministry of Agriculture (the same Ministry charged with enforcing the ban against the very GMOs that would be subject to royalty payment), who agreed to enforce the royalty payments. ${ }^{61}$ One month later, the government passed a special law legalizing the cultivation of GM soybeans in recognition of a material fait accompli in the countryside. ${ }^{62}$ Yet, another month later, the government created SENAVE, which could certify for exporters that the royalty had been paid.

SENAVE was a consolidation of a number of disorganized clientilistic agencies that became the competent agency for international communication about all things phytosanitary. Once in place, it attracted funding from IICA, FAO, and Japanese and German development agencies to build up its network of laboratories and training seminars. But more to the point, because it was financed by fees levied on wealthy producers, SENAVE was able to garner an enormous operating budget (by Paraguayan standards). SENAVE quickly extended its infrastructure throughout the countryside, setting up regional offices, border inspection points, laboratories, and certification programs.

59. The primary lobby group for the soy industry, the Union de Gremios Productivos (UGP), did of course continue to strongly oppose things like export taxation or land reform on which the speculation also depended. But this period also complexified the UGP's interests as well, forcing it to walk a fine line between populist anti-regulation positions in line with one kind of soybean, while it pushed for the creation of a more regular soybean on the other.

60. SEMINO, supra note 42 , at 17 .

61. Id. at 18 .

62. RoBIN, supra note 38 , at 276 . The special provision for Roundup Ready soybeans was not extended to other genetically modified organisms, which would henceforth have to go through a complicated approval process, and this would become one of the many terrains of struggle under Lugo's government. 
It is important here to differentiate what the soybean farmers thought they were doing in creating SENAVE from what the FAO thought it was doing. While the projects were coordinated through the canny translations of brokers like Dietze, they were clearly not the same. International agreements treat this form of regulation as a framework for trade. That is, regulation is separate from the commodities themselves, merely producing the conditions for their movement. Regulation effects this separation through the concept of information; that is, the object of regulation is not a thing per se but its representation. ${ }^{63}$ In this case, the harmonization of standards not only reduces things like soybeans to an objective singularity; it translates them into quantifiable units of communication within a larger system of harmonized language. We could call this the cybernetic model of regulation that posits the relationship between frame and object as analogous to the relationship between system and signal. In this framing practice, the global commodities market is produced and made optimally efficient by the reduction of noisy complexities to interpretable, quantifiable units of information. ${ }^{64}$

Regulators' self-description is closely mirrored by a critical literature that sees standards as a practice of disciplining through visibility. ${ }^{65}$ Elizabeth Dunn's work on the European Union's regulatory effects on Poland's food industry is exemplary here. Dunn argues that regulatory harmonization needs to be seen as producing certain kinds of human subjects. ${ }^{66}$ By increasing the legibility of certain labor practices to importing jurisdiction, the regulatory production of facts about the food industry creates a normative hierarchy in which the practices of

63. For a discussion of the separation of world from representation in modernist governmental epistemology, see generally TIMOTHY MITCHELL, RULE OF EXPERTS: EGYPT, TECHNO-POLITICS, MODERNITY (2002).

64. For a critique of the cybernetic model of development, based on the relationship between units of information and systems, see PHILIP MIROWSKI, MACHINE DREAMS: Economics BEcomes A CYBORG SCIENCE (2002); Kregg Hetherington, Promising Information: Democracy, Development, and the Remapping of Latin America, 41 ECON. \& SoC'Y 127 (2012).

65. This literature draws on Foucault's original work on regimes of visibility, and has become a common line of critique for standard-making practices and regimes of state surveillance in general. See, e.g., JAMES C. ScoTT, SEEING LIKE A STATE: How CERTAIN Schemes to IMPRove the Human Condition Have FaILed (1998); Arun Agrawal, Environmentality: Community, Intimate Government, and the Making of Environmental Subjects in Kumaon, India, 46 CURRENT ANTHROPOLOGY 161 (2005). See generally Michael Foucault, Discipline and Punish: THE BIRTH of THE PRISON (Alan Sheridan trans., Pantheon Books 1977) (1975).

66. Elizabeth Dunn, Standards and Person-Making in East Central Europe, in GLOBAL assemblages: Technology, Politics, and Ethics as ANTHropological Problems 173 (Aihwa Ong \& Stephen J. Collier eds., 2005) 
peripheral players in the market can be disciplined to more closely approximate those imagined to be in Western Europe. ${ }^{67}$ Indeed, though not subject to harmonization in the same way as Poland might be, the softer work of the FAO and IICA to bring Paraguay into the orbit of EU standards is quite closely related to it. So too was the hope I often heard voiced by urban activists, who thought that once SENAVE was run by someone like Lovera, it would be able to finally reveal, and thereby curb, all of the shady dealings going on in the soy industry. Their hope closely mirrored the project to reform Paraguayan soy producers in the mold of supposedly more transparent European subjects. ${ }^{68}$

That SENAVE did have an important effect on curbing certain practices (like pesticide smuggling) speaks to the disciplinary power of these normative understandings of information. And yet, neither of these versions of the power of information captures what soy farmers were up to when they chose to lobby so hard and pay so much to create the agency. For them, SENAVE's disciplinary role was secondary. SENAVE was equipped to produce large quantities of restricted data about agricultural production but very little in the way of grand representations that make visible its inner workings. Its mandate was in no way to "see like a state" in any grand way, nor was it equipped to produce critical facts about the industry for outsiders. Instead, it was almost exclusively about helping the industry deal with its increasing quantities of soybeans by allowing them to be articulated into other markets and practices. For instance, establishing new standards about humidity and purity made it much easier for multinational corporations like Cargill and Dreyfus to build silos, container fleets, and, later, industrial crushing facilities throughout the country, dramatically expanding the number of large-scale buyers available to soy farmers. But perhaps more importantly, certification of phytosanitary purity according to International Organization for Standardization (ISO) guidelines (once SENAVE was accredited) made it much easier to find overseas buyers for grains, since they could already be certified to meet the standards for purity and humidity demanded by importing jurisdictions.

From the industry perspective, a more useful way of thinking about such certification schemes is not that they produce legible facts about soybeans, but rather that they qualify soybeans and make them able to

67. Elizabeth C. Dunn, Privatizing Poland: Baby Food, Big Business, and the REMAKING OF LABOR (2004);; see also ANDREW BARRY, POLITICAL MACHINES: Governing A TECHNOLOGICAL SOCIETY (2001).

68. There is a certain irony here since most people involved in Lovera's group would balk at the imperialist undertones of this statement, and in slightly different contexts articulate deep criticisms of Western-styled industrial agriculture. 
do things they could not do prior to the availability of qualifying ritual. To adopt a phrase from Bernadette Bensaude-Vincent and Isabelle Stengers, what the test does is produce informed soybeans, matter augmented by information. ${ }^{69}$ An informed soybean is a soybean that comes accompanied by a piece of paper with legible data whose production has been certified (using stamps, signatures and an authoritative form) by a state representative. While the bean may have the exact chemical composition of any other bean, it is also something more, augmented by the nearby presence of the form, with its numbers and stamps. If, as Latour has said, a fact is a state of the world loaded into a statement, then what an agency like SENAVE does is load statements back into states of the world. ${ }^{70}$ The certificates are based on representational practices, but they are representations that never travel far from their referents. Rather, they improve soybeans to make them capable of passing very particular sorts of trials: import inspections in other jurisdictions. Informed soybeans store better, travel better, win the approval of clients better, and generally make for a much better, more versatile commodity. Indeed, most people I have spoken to (including inspectors, farmers, and lobbyists, as well as their critics) acknowledge that, in the period prior to Lovera's presidency and while the UGP controlled policy making in the boardroom of SENAVE, all parties understood that on-farm inspections were opportunities for bribery. In both legitimate and illegitimate ways, the UGP was said to "own" SENAVE,71 which, in their perspective, seemed less like a state agency than like a rather prosaic piece of the export chain.

\section{ThIRD TRanslation: The STATE AND Human Bodies}

The creation of SENAVE proved to be a very effective strategy for the commodification of soybeans, and the years after it was inaugurated saw multinational corporations such as Cargill and Dreyfus setting up silos, crushing facilities, and ports throughout the countryside and along all major highways. And yet, SENAVE did not only enact

69. BernadetTe Bensaude-Vincent \& IsaBelle Stengers, A History of Chemistry (Deborah van Dam trans., Harvard University Press 1996) (1993); see also Andrew Barry, Materialist Politics: Metallurgy, in Political MatTer: TeChnoscience, Democracy, AND PUBLIC LIFE 89 (Bruce Braun \& Sarah J. Whatmore eds., 2010).

70. BRuno Latour, Circulating Reference, in PANDORA's HOPE: Essays ON THE REALITY OF SCIENCE STUDIES 24, 48 (1999).

71. Nickson and Lambert make the argument that during the 1990s (and I would say thereafter), institutional reformers in Paraguay had to deal with the long legacy of oligarchies treating the state as their private property. SENAVE falls very much into this category. Andrew Nickson \& Peter Lambert, State Reform and the 'Privatized State' in Paraguay, 22 PUB. ADMIN. \& DEv. 163, 167 (2002). 
soybeans as commodities. In less obvious ways, by building up the phytosanitary capabilities of the state, soybeans also came to be understood increasingly as plants (rather than only as commodities) whose regulatory interests and problems fell into the same category as other plants that concerned humans. Through its categorization as a plant, soybeans became entangled in a whole other set of associations that were less obviously beneficial to the industry.

The very concept of "phytosanitary regulation" is a fickle bundle of concerns, at least two of which were inconvenient for the soy industry: border control and food safety. First, SENAVE was designed to frame a very particular scale-that of the nation-state-in which a centralized bureaucracy can control the movement of objects and people across terrestrial borders. Much of the international energy put into international phytosanitary agreements in the $1990 \mathrm{~s}$ was meant to counterbalance the new pest vectors opened up by increased trade. ${ }^{72} \mathrm{It}$ is worth remembering that the first phytosanitary measure (and still among its most common-and bluntest-instruments) was the quarantine, whereby central states could at least attempt to prevent the passage of plant pests from one agricultural area into another. ${ }^{73}$ This same logic would be applied to agrichemicals under the Rotterdam Convention of 1998. So while phytosanitary agreements were pushed as "trade enabling," they accomplished this primarily by encouraging tighter state control over the movement of plants and chemicals. Soy farmers who reviled the state now found themselves paying substantial fees to have state actors nose around in their business. The agency may have been seen as the private property of the soy industry in real terms, but it nonetheless implied converting beans that had once thrived on a porous land border into a properly national sort of thing.

The second bundle of concerns was even more delicate. Another major impulse for phytosanitary regulation came from increased concerns in Europe in the 1990s over food safety. ${ }^{74}$ Although soybeans grown in Paraguay do enter the human food chain, mostly as chemical derivatives, or as meats derived from animals raised on soy meal, they are not consumed fresh and are therefore subject to almost no controls

72. Most new international agreements came out of agreements between the Food and Agriculture Organization (FAO) and the World Trade Organization (WTO). See DAVID L. EbBEls, PRinciples of Plant Health AND QuARANTINe 33 (2003).

73. See generally id.

74. For a discussion of the "monstrous topicality" that linked GM soybeans to mad cow disease and other food scares in Europe, see SARAH WHATMORE, HYBRID GEOGRAPHIES 120 (2002). In fact, the same activist networks that raised the alarm about genetically modified organisms in Europe were involved in publicizing campesino critiques of soybeans in Paraguay, and in propagating the slogan that "soy kills." See Hetherington, supra note 24 , at 78 . 
themselves as food objects.75 Indeed, part of the frustration of soy farmers about the GMO scares of the early 2000s in Paraguay was that they seemed to be based on the belief that people would be eating large quantities of GMOs, which they generally were not. ${ }^{76}$ SENAVE's regulation of the soybean is entirely in agreement with the soy lobby itself. SENAVE officially claims that soybeans do not pose a serious problem as food. But according to the logic of phytosanitary regulation, concerns that are appropriate to soybeans (such as silo humidity standards) are dealt with by the same agencies as concerns about toxic residues on imported tomatoes sold in local markets. At the very least, since files about pesticide residues on tomatoes sit on the same desk as files about silo humidity, whether or not the connection is made depends to some extent on the person sitting at the desk. During Lovera's tenure at SENAVE, one of the great controversies would be whether soybeans needed to be linked to the Ministry of Public Health. ${ }^{77}$

That this association between soybeans and health was controversial can be seen in the legal documents going back to the early 1990s, when the Ministry of Public Heath became involved in legislative pushes to control pesticide use. ${ }^{78}$ Before and after its creation, the soy lobby haggled with other parties over whether SENAVE ought to facilitate input from the Ministry of Public Health and the Secretariat of the Environment into decisions about certifying GMOs or whether these should remain decisions exclusively of SENAVE. Lovera would ultimately fail to formalize the link, but informal lines of communication between his office and the Ministry of Public Health remained strong throughout his mandate, as did his determination to reframe plant health in terms of human health. ${ }^{79}$

75. See Ivan Sergio Freire de Sousa \& Rita de Cássia Milagres Teixeira Vieira, Soybeans and Soyfoods in Brazil, with Notes on Argentina: Sketch of an Expanding World Commodity, in THE WORLD OF SoY, supra note 2, at 234.

76. The exception to this rule were the occasional times soy farmers donated large quantities of milk to schools as part of a local campaign to make themselves appear more generous.

77. This was all the more complicated politically for the UGP since if there was one success under Lugo that attracted almost universal support and admiration it was his reform of the Ministry of Public Health and the proliferation of health services in the countryside. The otherwise tangential detail that Lovera was on very good terms with the popular new Minister of Public Health, Esperanza Martínez, became quite important in this context.

78. See, e.g., Organización Panamericana de la Salud [Pan-American Health Organization], Simposio InTERnaCional SOBRE InSECTICIDAS, PLAGUICIDAS Y DESEChOS Toxicos en el Paraguay IINTERnational SyMPosium ON INSECTICIDES, PESTICIDEs, AND TOXIC WASTE IN PARAGUAY] (1993) (Para.).

79. The approval body for genetically modified organisms, the Comite de Bioseguridad, was made of representatives from different ministries and agencies. In the end, the 
Since the expansion of soybeans had become controversial, the case to garner the most public outrage against the sector was the poisoning death of Silvino Talavera, an eight-year-old boy who was sprayed by a crop duster on his way home from school. ${ }^{80}$ While cases like this one were widely rumored to have occurred throughout the countryside, this was the first one in which a team of activists and lawyers managed to get medical proof, in the form of tests on the boy's blood-performed in Buenos Aires-that pesticides killed him. Linking pesticides to the body of a child made the case emblematic in the public sphere of the dangers of soybeans and the arrogance of the industry. ${ }^{81}$ There were of course epidemiological nuances here that the soy lobby was always happy to point out even a decade later: Silvino's reaction to exposure was exacerbated by malnourishment and other diseases of poverty that were not precisely the fault of the farmers who had exposed him to pesticides. But the very fact that this argument was made shows just how ethically weak their position had become.

Shortly after the Silvino case went public, the Ministry of Agriculture put a new pesticide law in place that required farmers to plant barrier vegetation between their fields and the houses of their neighbors. ${ }^{82}$ It was a hastily-devised and difficult to enforce regulation, but it became part of the conversation from that point onward. The same year, a task force was established with the help of IICA and FAO to study Paraguay's pesticide regulations, and this task force eventually recommended an overhaul of legislation covering the use of agrichemicals, including tougher penalties and restrictions. The task force's discussion was influenced in part by the Talavera controversy and was highly unpopular with the soy lobby, which was able to have it scuttled in the Senate and replaced with their own less restrictive Law $2457 / 09$. In response to this political play in the legislature, Lugo named Miguel Lovera to head the SENAVE, who in turn called Silvia González, the lead lawyer on the Silvino Talavera case, and a good friend of the Ministry of Public Health's main epidemiologist. Lovera asked her to head SENAVE's legal department. She immediately began, among other things, to draft a decree that would increase the restrictiveness of law $2457 / 09$ by redefining its key terms (e.g. barrier, notification, neighborhood). The regulation could bypass the Senate because it did

Ministry of Public Health would be represented only by the National Institute of Nutrition, rather than those institutes concerned with the consequences of pesticide use.

80. See Hetherington, supra note 24 , at 78 .

81. See id. at 79 .

82. Decreto No. 2.048/04, 26 de Marzo de 2004 (Para.), available at http://www.senave. gov.py/docs/decretos/Dto2048-04.pdf. 
not need to be passed as a law but only as a decree of the Minister of Agriculture.

What all of these minute details of regulatory haggling underline is just how much all of the actors understood regulation and standard setting as a site of innovation (to use Yasmine Chahed's term from her contribution to this collection). But they were not merely innovating in the realm of policy. Under Lovera's administration, we can see yet another bean emerging, if only partially, one that is linked to concerns about the effects of pesticide use on human health. All of this was made possible by the fact that the overriding regulatory framework to emerge in the period of soybean commodification also treated soybeans as plants and food objects. Since SENAVE had already effected a reterritorialization of soybeans, framing them in national terms, it seemed plausible to think that they would become ever more entwined with human bodies through regulatory relationships between the ministries of Agriculture and Public Health. The UGP pulled out all the stops to try to prevent González from interfering with the pesticide legislation and managed to convince the Minister of Agriculture not to sign it. Instead of passing a decree, then, Lovera turned it into a "resolution," an inferior layer of law signed by the head of the institution rather than the Minister that could dictate how inspectors were to interpret the law. ${ }^{83}$ It is telling that when Lovera was turfed by the new government in June 2012, one of the first acts of the new president of SENAVE was to tell his inspectors that this resolution was no longer in effect. The new president never bothered to officially overturn it because it was simply understood that, in the climate of the coup, he could if he wanted to.

\section{The ONTOLOGiCAL Politics of a COUP}

Had president Lugo not been deposed, and had Lovera and his team not been sacked from SENAVE, a rather different analysis might have been tempting. Lugo had come to power on a promise of a more equitable society with tighter controls on environmental and economic exploitation, using the power of the regulatory framework to turn a longstanding critique of the soy sector into an instrument for limiting and containing. In that light, small acts of regulatory tinkering were bound to be a disappointment to the activist supporters of his government. The story I have just told about trying to couple soybeans to bureaucratic processes in the Ministry of Public Health could be

83. Resoluciones del SENAVE, No. 550, 21 de Julio de 2011 (Para.), available at http:// www.senave.gov.py/docs/resoluciones/senave/Res550-11.pdf. 
supplemented by many others about chemistry lab equipment purchasing agreements and community mapping practices. If one wishes to evaluate regulatory practices as creating frameworks that contain and thereby control soybeans understood as a singular kind of stable object, then none of these efforts could be deemed successful. If, however, we see each of these attempts as enrolling new relationships into the soybean assemblage and making the soybeans capable of new things, we are able to ask a whole new set of questions, much closer, I think, to what Lovera asked himself when he took over SENAVE and the UGP was asking itself when it pressured for a coup.

Soybeans had, after all, become a mega-crop in Paraguay only because of their uncanny ability, with Brazilian migrants, to make speculative connections across the regulatory differences straddling Paraguay's borders. The UGP worked hard to build SENAVE, enrolling new relationships to help produce a more robust soybean for international markets, only to see yet another bean emerge, a nationalist bean that respected borders and colluded with the state. All of this made soybeans fickle but powerful things, ontologically cunning things that promised riches even as they warned of how many other things they might become. What emerged from the meetings between SENAVE and the Minister of Public Health was the possibility of a new bean, one irreducibly connected to the health of the rural poor. Such a bean might thrive, not on the exclusion of human bodies like that of Silvino Talavera-malnourished, exhausted, and, finally, poisoned-but on its connection to them, and, as such, seriously undermine the economic projects that were built around them.

Whether it is successful or not in reframing soybeans so as to keep them distinct from the concerns of sickened human bodies, it is notable that the moment of framing in this story took place not through regulation but through an overthrow of government. Only in the light of the parliamentary coup can one fully appreciate the ontological posture of the soy lobby and the lengths it was willing to go to maintain control and to cut the network in the hopes of preventing such new connections from becoming indispensable. In the post-critical moment that Paraguayan activists had to contend with when they were elected in 2008 , these pragmatic moves of apparently minute regulatory translation were capable of stirring the fears of a powerful economic group, not by taking away, but by adding concerns to the thing in question. For social legal scholars also grappling with the politics of analysis beyond critique, it is worth remembering what regulation can make, rather than focusing on what it ought to control. 